\title{
DAMPAK SOSIO-RELIGIUS PUTUSAN MAHKAMAH AGUNG NOMOR 420 K/AG/2010 TERHADAP WARIS ANAK ANGKAT DAN PARA PIHAK PERSPEKTIF KOMPILASI HUKUM ISLAM
}

\author{
Agus Sukari \\ Mahasiswa Hukum Keluarga Islam Fakultas Syariah IAIN Kudus \\ Email:nusantaraku2015@yahoo.com
}

\begin{abstract}
This article aims to analyze the decision of the Pati Religious Court Number 1152/Pdt.G/2008/PA.Pt, Keputusun Religious High Court Semarang Number 35/Pdt.G/2010/PTA.Smg, to the Supreme Court decision Number 420K/AG/ 2010 regarding the distribution of the inheritance of adopted children. This article a type of literature review using a qualitative approach method. The results of the research study indicate that the polemic of giving inheritance between the heirs and adopted children in the Supreme Court Decision Number 420K/AG/2010 uses the provisions of the Islamic Law Compilation (KHI). The Supreme Court in its decision stated that the injunction of the Semarang High Religious Court which strengthened the decision of the Pati Religious Court must be corrected by considering the object of the dispute in the form of joint assets, so that joint assets must first be divided between the deceased and the heirs.
\end{abstract}

Keywords: Inheritance Rights, Adopted Children, Compilation of Islamic Law

\begin{abstract}
Abstrak
Artikel ini bertujuan untuk menganalisis keputusan Pengadilan Agama Pati Nomor 1152/Pdt.G/2008/PA.Pt, Keputusun Pengadilan Tinggi Agama Semarang Nomor 35/Pdt.G/2010/PTA.Smg, hingga putusan Mahkamah Agung Nomor 420K/AG/2010 tentang pembagian waris anak angkat. Artikel ini merupakan jenis kajian kepustakaan dengan menggunakan metode pendekatan kualitatif. Hasil kajian penelitian menunjukkan bahwa polemik pemberian harta waris antara ahli waris dan anak angkat dalam Putusan Mahkamah Agung Nomor 420K/AG/2010 menggunakan ketentuan Kompilasi Hukum Islam (KHI). Mahkamah Agung dalam putusannya menyatakan bahwa amar putusan Pengadilan Tinggi Agama Semarang yang menguatkan putusan Pengadilan Agama Pati harus diperbaiki dengan pertimbangan objek sengketa yang berupa harta bersama maka harta bersama harus dibagi terlebih dahulu antara almarhum dan ahli waris.
\end{abstract}

Kata Kunci: Hak Waris, Anak Angkat, Kompilasi Hukum Islam 


\section{PENDAHULUAN}

Keberadaan anak merupakan harapan semua pasangan rumah tangga. Namun tidak semua beruntung memiliki anak kandung biologis. Anak selain menjadi harapan dan teman di masa tua, juga diharapkan dapat menjadi ahli waris. Keinginan untuk mempunyai seorang anak adalah naluri manusiawi dan alamiah. Akan tetapi pada kenyataannya tidak jarang sebuah rumah tangga tidak memiliki anak. Maka untuk melengkapi unsur keluarga itu dan atau untuk melanjutkan keturunannya dapat dilakukan suatu perbuatan hukum yaitu dengan mengangkat anak (Masturi, 2017: 2).

Dalam Islam anak angkat tidak berhak menjadi ahli waris. Namun ia berhak mendapatkan hibah dari orang tua angkatnya. Perkara kewarisan ini merupakan suatu peristiwa penting bagi seorang manusia ketika manusia tersebut meninggal dunia,sebab terjadi perpindahan harta benda dari seorang manusia kepada manusia lainnya. Dengan kata lain pewarisan adalah aturan mengenai apa yang harus terjadi dengan hartakekayaan seseorang yang telah meninggal dunia atau pewaris kepada ahli warisnya.

Kewarisan berarti menentukan siapa-siapa yang menjadi ahli waris, porsi bagian masing-masing ahli waris, menentukan harta warisan bagi orang yang meninggal. Dasar hukum waris Islam adalah al-Qur'an dan Hadis, peraturan perundang-undangan, Kompilasi Hukum Islam, pendapat ahli hukum Islam.

Warisan adalah suatu cara penyelesaian perhubunganperhubungan hukum dalam masyarakat, yang melahirkan sedikit banyaknya kesulitan akibat meninggalnya seseorang (Ash-Shiddieqy, 2001: 5). Inpres Nomor 1 Tahun 1991 tentang Kompilasi Hukum Islam merupakan salah satu unifikasi hukum Islam di Indonesia yang menampung aspirasi masyarakat. Pada Buku II pada Instruksi presiden tersebut mengatur tentang kewarisan yakni mulai dari perihal kewarisan sampai kepada hibah. Inpres ini merupakan pengaturan mengenai kewarisan yang berdasarkan pada hukum waris Islam adalah al-Qur'an dan Hadis.

Dalam Inpres Nomor 1 Tahun 1991 tentang Kompilasi Hukum Islam dijelaskan bahwa:"Hukum kewarisan adalah hukum yang mengatur tentang pemindahan hak pemilikan harta peninggalan (tirkah) pewaris, menentukan siapa-siapa yang berhak menjadi ahli waris dan berapa bagiannya masing-masing".

Dengan jatuhnya tanah kepada ahli waris, maka terjadilah pemilikan bersama tanah hak milik jika tanah tersebut hanya satusatunya. Untuk memperoleh kekuatan pembuktian tanah dari hasil pewarisan, maka surat keterangan waris diperlukan. Kewarisan merupakan suatu perbuatan hukum yang tentunya akan menimbulkan 
akibat hukum (Ridwan, 2010: 306). Seorang pewaris yang pada saat meninggalnya atau dinyatakan meninggal berdasarkan putusan pengadilan beragama Islam meninggalkan ahli waris dan harta warisan, namun setelah meninggalnya pewaris tersebut harta warisan tadi menjadi milik ahli waris. Akibat hukum ini juga terkait dengan sah tidaknya suatu perbuatan hukum.

Hukum Waris yang berlaku di Indonesia ada tiga yakni Hukum Waris Adat, Hukum Waris Islam dan Hukum Waris Perdata yang menganut dari Burgerlijk Wetboek. Setiap daerah memiliki hukum yang berbeda-beda sesuai dengan sistem kekerabatan yang mereka anut. Berdasarkan Surat Mahkamah Agung Republik Indonesia pada tanggal 8 Mei 1991 Nomor MA/kumdil/171/V/K/1991 ditentukan mengenai ketentuan kewenangan hukum berdasarkan masing-masing kelompok Penduduk di Indonesia. Namun setelah lahirnya Instruksi Presiden Republik Indonesia Nomor 1 Tahun 1991 tanggal 10 Juni 1991 atau yang disebut Kompilasi Hukum Islam (KHI), masalah Pewarisan bagi Penduduk Indonesia yang beragama Islam diatur dalam Buku II Hukum Kewarisan (Pasal 171-214) KHI tersebut, adapun lembaga pengawas atas pewarisan tersebut adalah Peradilan Agama.

Pengadilan Agama berwenang mengeluarkan Fatwa atau penetapan mengenai Pembagian Harta Peninggalan seorang pewaris yang beragama Islam. Kewenangan ini berdasarkan ketentuan Pasal 49 huruf b Undang-Undang Nomor 3 Tahun 2006 tentang Perubahan atas Undang-Undang Nomor 7 Tahun 1989 tentang Peradilan Agama. Fatwa Waris dikeluarkan oleh Pengadilan Agama atas dasar permohonan ahli waris. Fatwa Waris berlaku sebagai keterangan siapa saja yang berhak untuk mewarisi harta peninggalan si Pewaris (ahli waris). Berdasarkan Fatwa Waris tersebut, Notaris/PPAT dapat menentukan siapa saja yang berhak untuk menjual tanah warisan dimaksud.

Menurut ketentuan umum dalam Kompilasi Hukum Islam Pasal 171 bahwa anak angkat adalah anak yang dalam hal pemeliharaan untuk hidupnya sehari-hari, biaya pendidikan dan sebagainya beralih tanggungjawabnya dari orang tua asal kepada orang tua angkatnya berdasarkan putusan pengadilan. Berdasarkan pengertian tersebut telah dijelaskan bahwa yang dilarang menurut Hukum Islam adalah pengangkatan anak sebagai anak kandung dari berbagai sisi. Terdapat titik persilangan menurut ketentuan hukum adat, yang menghilangkan kedudukan anak angkat dengan orang tua kandungnya sendiri karena terdapat ketentuan yang menghilangkan hak-hak ayah kandung dan dapat merombak ketentuan-ketentuan mengenai waris. Dengan demikian, maka sudah selayaknya apabila ada suatu cara untuk menjembatani masalah anak angkat, sehingga anak angkat dapat dipelihara dengan baik dan dapat terjamin masa depannya khususnya yang berkaitan dengan 
bagian waris anak angkat yang bersangkutan.

Sistem hukum Indonesia masih terjadi kemajemukan tatanan hukum. Masalah pewarisan pun ada tiga sistem hukum waris yang berlaku dan diterima oleh masyarakat Indonesia, yaitu bagi warganegara Indonesia asli masih tetap berlaku hukum waris adat yang diatur menurut susunan masyarakat adat, yang bersifat patrilinial, matrilineal, dan parental/bilateral. Di samping itu bagi keluargadi Indonesia yang mentaati hukum agamanya, melaksanakan pewarisan sesuai dengan ajaran agamanya masing-masing. Bagi keturunan Eropa dan Timur Asing masih tetap berlaku hukum waris perdata yang diatur (Hadikusuma, 2010: 2).

Masalah waris sering kali menimbulkan masalah dalam kehidupan sehari-hari. Masalah ini sering kali muncul karena adanya salah satu ahli waris yang merasa tidak puas dengan pembagian warisanyang diterimanya. Hal ini timbul dari sifat serakah manusia yang berkeinginanuntuk selalu mendapatkan yang lebih dari apa yang telah diperoleh. Untuk mendapatkan harta warisan sesuai dengan jumlah yang diinginkan, para ahli waris menempuh segala cara yang dapat dilakukan guna mencapai tujuanya, baik melalui jalan hukum maupun dengan jalan melawan hukum. Jika perolehan harta waris dilakukan dengan jalan melawan hukum, sudah tentu ada sanksi hukum yang menanti para pihak yang melakukan.

Kajian penelitian ini menfokuskan tentang bagaimana Keputusan Pengadilan Agama Pati Nomor 1152/Pdt.G/2008/PA.Pt tentang Pembagian Waris Anak Angkat, bagaimana Keputusun Pengadilan Tinggi Agama Semarang Nomor 35/Pdt.G/2010/PTA.Smg tentang Pembagian Waris Anak Angkat, bagaimana pertimbangan Mahkamah Agung dalam putusan Nomor 420K/AG/2010 tentang Pembagian Waris Anak Angkat. Dengan fokus permasalahan tersebut, maka kajian penelitian ini bertujuan untuk menganalisis keputusan Pengadilan Agama Pati Nomor 1152/Pdt.G/2008/PA.Pt tentang Pembagian Waris Anak Angkat, untuk menganalisis keputusun Pengadilan Tinggi Agama Semarang Nomor 35/Pdt.G/2010/PTA.Smg tentang pembagian waris anak angkat, untuk menganalisis pertimbangan Mahkamah Agung dalam putusan Nomor 420K/AG/2010 tentang pembagian waris anak angkat.

\section{METODE PENELITIAN}

Tulisan artikel ini merupakan jenis penelitian kepustakaan (library research) dengan menggunakan pendekatan kualitatif. Data yang digunakan adalah data sekunder yaitu data yang diperoleh dengan kajian kepustakaan, yaitu mencakup: (1) Bahan hukum primer yaitu kaidah dasar (Pancasila), Undang-Undang Dasar Republik 
Indonesia 1945, Kompilasi Hukum Islam (KHI); (2) Bahan hukum sekunder yaitu bahan hukum yang memberikan penjelasan mengenai bahan hukum primer, seperti pendapat para ahli, hasil karya ilmiah, artikel, makalah, jurnal ilmiah, dan hasil penelitian terdahulu; dan (3) Bahan Hukum Tersier yaitu data yang diberikan petunjuk maupun penjelasan terhadap bahan hukum primer dan sekunder yang terdiri atas kamus hukum, kamus Bahasa Indonesia, dan sumber data lainnya misalnya internet. Metode pengumpulan data yang digunakan adalah dokumentasi, wawancara, dan observasi. Untuk proses wawancara informan yang diperoleh yakni para hakim yang bertugas di Pengadilan Agama Pati.

\section{PEMBAHASAN}

\section{Diskripsi Kasus}

Kronologi kasus yang hendak dibahas yaitu bahwa dahulu di Desa Kauman, Kecamatan Juwana, Kabupaten Pati pernah hidup sepasang suami istri yaitu Tardjo alias Sutardjo (almarhum) dan Karyati (Almarhumah) yang mana dalam pernikahan tersebut dikaruniani 7 orang anak, masing-masing bernama: (1) $\mathrm{Hj}$. Katidjah 59Tahun, (2) H. Tardjuki (Almarhum), (3) H. Taryono 48 Tahun, (4) Hj. Karminah 47 tahun, (5) Katini 44 Tahun, (6) Hj. Karyani 38 Tahun, dan (7) Karmiyati 36 Tahun. Kemudian H. Tardjuki bin Tardjo alias Sutardjo menikah dengan $\mathrm{Hj}$. Winarti binti Rasdi (selaku Tergugat) dan dalam pernikahan tersebut tidak dikaruniai anak sehingga dalam pernikahannya dengan $\mathrm{Hj}$. Winarti binti Rasdi tersebut mengangkat seorang anak laki-laki bernama Alvino Aryananda (yang turut menjadi Tergugat dalam kasus ini).

Dalam hal ini H. Tardjuki bin Tardjo alias Sutardjo telah meninggal dunia pada tanggal 6 Oktober 2007 dan meninggalkan beberapa harta bawaan atau harta asal yang hendak diwariskan. Selain harta bawaan atau harta asal, H. Tardjuki bin Tardjo alias Sutardjo juga meninggalkan harta bersama (gono gini) yang diperoleh dalam pernikahannya dengan Tergugat berupa simpanan/deposito barang bergerak dan barang tidak bergerak, serta meninggalkan harta warisan berupa hak sewa tambak.

Sengketa kewarisan yang kerap menjadi permasalahan keluarga yang kemudian berlanjut menjadi perkara di Pengadilan Agama tidak jarang terjadi disebabkan oleh penguasaan harta peninggalan orang tua angkat oleh pihak-pihak tertentu yang sangat jauh dari prinsip keadilan menurut pandangan para pihak maupun hukum Islam, yaitu penguasaan harta peninggalan orang tua angkat hanya oleh anak angkat saja, atau oleh ahli waris saja, atau bahkan dengan sesama anak angkat. Intinya adalah tidak tercapainya kesepakatan antara para ahli 
waris dan anak angkat mengenai bagian hak mereka, tidak dirasakannya keadilan oleh masing-masing pihak, satu pihak merasa lebih berhak dari pihak yang lain karena kurangnyapengetahuan tentang hak-hak dan kewajiban-kewajiban masing-masing pihak (yang sudah ditentukan menurut hukum Islam), yang oleh karenanya perananpengadilan sangat dibutuhkan.

Dari kasus tersebut, masing-masing peradilan memutuskan dalam tiaptingkatan Peradilan sebagai berikut:

(1) Dalam peradilan tingkat Pertama;

Penggugat memenangkan perkara

(2) Dalam tingkat Banding;

Pengadilan Tinggi Semarang menguatkan putusan Pengadilan Agama Pati

(3) Dalam tingkat Kasasi;

Putusan-putusan baik ditingkat pertama dan tingkat Banding dibatalkan seluruhnya oleh Mahkamah Agung

Putusan Pengadilan Agama Pati Nomor 1152/Pdt.G/2008/PA.Pt tentang Pembagian Waris Anak Angkat

Perkara diajukan ke Pengadilan Agama Pati oleh Para Penggugatyang merupakan ahli waris orang tua angkat, pada tanggal 9 November 2009. Adapun pertimbangan hukum dan Putusan Hakim Pengadilan Agama Pati adalah:

1. Hakim menyampaikan bahwa dari bukti-bukti surat mengenai Obyek Sengketa dan didukung oleh keterangan para saksi. Dapat dibuktikan semua tanah obyek sengketa adalah milik Pewaris (harta asal), yang dahulunya milik orang tuanya, sehingga tanah obyek sengketa merupakan harta bawaan atau harta asal dari Pewaris;

2. Obyek sengketa yang merupakan harta asal kembali ke atas, sedangkan pemilik telah meninggal dunia, maka obyek sengketa diwariskan kepada anak atau keturunan almarhum yang masih hidup yaitu para Penggugat;

3. Karena yang berhak atas obyek sengketa adalah Para Penggugat, maka obyek sengketa yang merupakan hak sewa tanah yang lah dilakukan Pewaris ketika masih hidup harus dibagi rata oleh Tergugat, menguasai harta waris sendirimerupakan tindakan yang tidak sah dalam hukum dan harus menyerahkan obyek sengketa kepada para Penggugat dalam keadaan kosong tanpa beban dan syarat, bahkan bila diperlukan dengan bantuan pihak berwajib;

4. Majelis hakim memutuskan mengabulkan sebagian gugatan para ahli waris dari almarhum Pewaris dan memutuskan bahwa para ahli waris dari Pewaris berhak atas harta warisan secara merata di mata hukum; 
5. Pihak anak angkat merupakan anak angkat yang sah, namun masih di bawah umur sehingga mendapat "wasiat wajibah" harta peninggalan dari orang tua angkatnya (Putusan PA Pati Nomor 1152/Pdt.G/2008/PA.Pt

Setelah dari keterangan bukti tulis dan keterangan saksi salingmendukung akhirnya menjadi fakta hukum, yang dimana fakta itu akandijadikan acuan oleh hakim untuk mempertimbangkan pokok masalahnya dalam perkara tersebut. Perkara sengketa pembagian warisan, kedua belah pihak mengajukan alat bukti.

Dalam menentukan suatu putusan, seorang hakim berpegang dalam tiga aspek yaitu legal justice, social justice dan moral justice. Hakim dalam memberikan pertimbangan mengenai putusan yaitu menghubungkan gugatan para penggugat, jawaban para tergugat, dan alat-alat bukti yang diajukan oleh kedua belah pihak, selanjutnya peristiwa tersebut dihubungkan dengan peraturan perundangundangan (Daud, 2012). Adapun isi dari putusan Pengadilan Agama Pati Nomor 1152/Pdt.G/2008/PA.Pt adalah:

1. Mengabulkan gugatan para penggugat untuk sebagian;

2. Menyatakan sita jaminan atas objek sengketa sah dan berharga;

3. Menetapkan bahwa penggugat I-VI adalah saudara-saudara kandung almarhum H. Tardjuki bin Tardjo alias Sutardjo, dan Tergugat adalah janda almarhum H. Tardjuki bin Tardjo alias Sutardjo serta mereka adalah para ahli waris almarhum H. Tardjuki bin Tardjo alias Sutardjo;

4. Menetapkan bahwa Alvino Aryanda (Turut Tergugat) adalah anak angkat almarhum H. Tardjuki bin Tardjo alias Sutardjodalam perkawinan dengan Tergugat, dan berhak mendapatkan wasiat wajibah atas harta warisan almarhum H. Tardjuki bin Tardjo alias Sutardjo;

5. Menetapkan bahwa almarhum H. Tardjuki bin Tardjo alias Sutardjo dalam perkawinannya dengan Tergugat sebelumnya telah membawa harta bawaan (asal) dan harta bersama (gono gini);

6. Menetapkan bahwa besarnya bagian masing-masing ahli waris almarhum H. Tardjuki bin Tardjo alias Sutardjo terhadap harta bawaan (asal) dan harta bersama (gono gini);

7. Menghukum Tergugat maupun siapapun yang memperoleh hak dari padanya untuk menyerahkan harta warisan almarhum $\mathrm{H}$. Tardjuki bin Tardjo alias Sutardjoyang menurut hukum menjadi hak dan bagian para Penggugat sebagai ahli waris dari almarhum $\mathrm{H}$. Tardjuki bin Tardjo alias Sutardjo;

8. Menghukum Tergugat untuk membayar uang paksa (dwangsom) sebesar Rp. 1.000.000,- (satu juta rupiah) untuk setiap harinya atas keterlambatan pelaksanaan penyerahan harta warisan almarhum $\mathrm{H}$. 
Tardjuki bin Tardjo alias Sutardjo yang menjadi hak bagian para Penggugat;

9. Menolak gugatan para Penggugat selain dan selebihnya;

10. Menghukum Tergugat untuk membayar seluruh biaya perkara.

Alasan-alasan yang telah diajukan oleh para Penggugat dalam gugatannya,disimpulkan yang menjadi pokok sengketa antara kedua belah pihak adalah berkaitan dengan harta peninggalan almarhum dan almarhumah, atas obyek sengketa yang belumdibagi waris. Selain itu adanya niat dari Tergugat untuk menguasai harta waris sendiri merupakan faktor yang menyebabkan adanya pengajuan gugatan dalam kasus sengketa hak waris ini.

\section{Putusan Pengadilan Tinggi Agama Semarang Nomor 35/Pdt.G/2010/PTA.Smg tentang Pembagian Waris Anak Angkat}

Putusan Pengadilan Agama Pati pihak Tergugat mengajukan permohonan banding kepada Pengadilan Tinggi Agama Semarang. Pertimbangan dan Putusan Hakim Pengadilan Tinggi Agama Semarang adalah:

1. Dari alasan-alasan yang telah diuraikan serta dikemukakan oleh Majelis Hakim Pengadilan Tingkat Pertama pada putusannya tersebut adalah sudah tepat dan benar menurut hukum, sehingga dengan demikian dapat diterima, disetujui dan dijadikan sebagai dasar serta pendapat Majelis Hakim PTA Semarang sendiri dalam memutuskan perkara di peradilan tingkat banding;

2. Berdasarkan pertimbangan hukum tersebut Majelis Hakim PTA Semarang memutuskan menguatkan Putusan Pengadilan Agama Pati Nomor 1152/Pdt.G/2008/PA.Pt;

3. Membebankan kepada Pembanding untuk membayar biaya perkara tingkat banding sebesar Rp. 150.000,- (seratus lima puluh ribu rupiah).

Dari pernyataan di atas, Hakim memutuskan untuk mengabulkan Permintaan Tergugat meskipun Tergugat telah mendatangkan beberapa saksi untuk membuktikan pernyataan Tergugat tersebut. Hal ini didasari oleh KHI bahwa anak angkat tidak memiliki hak untuk mendapatkan hak waris orang tua angkat, tetapi hanya berhak mendapatkan Wasiat Wajibah dari orang tua angkat maksimal sepertiga bagian dari harta orang tua angkat. Selanjutnya dalam Kompilasi Hukum Islam menyatakan bahwa penggugat selaku saudara kandung almarhum Pewaris juga mempunyai hak atastanah sawah, tegal, pekarangan untuk diserahkan dandibagi waris antara para penggugat dan para tergugat dan turut paratergugat ahli waris cucu almarhum sebagai pengganti ahli waris almarhum mendapat bagian sama rata dari tanah sengketa. 


\section{Pertimbangan Mahkamah Agung dalam Putusan Nomor 420K/AG/2010 tentang Pembagian Waris Anak Angkat}

Putusan yang diambil oleh Pengadilan Tinggi Agama Semarang yang menguatkan putusan Pengadilan Agama Pati, pihak tergugat selaku janda dari almarhum pewaris mengajukan permohonan Kasasi ke Mahkamah Agung, di mana permohonan kasasi beserta alasan yang telah diberitahukan kepada pihak penggugat, diajukan dalam tenggang waktu dan cara yang ditentukan undang-undang, maka oleh karena itu permohonan Kasasi tersebut formil dapat diterima. Pertimbangan Hukum Majelis Hakim Mahkamah Agung:

1. Bahwa alasan tersebut telah benar karena judex facti tidak dapat dan tidak salah dalam menerapkan hukum lagipula hal ini pada hakekatnya mengenai penilaian hasil pembuktian yang bersifat penghargaan tentang suatu kenyataan hal mana tidak dapat dipertimbangkan dalam pemeriksaan dalam tingkat kasasi karena pemeriksaan dalam tingkat kasasi hanya berkenan dengan adanya kesalahan penerapan hukum adanya pelanggaran hukum yang berlaku adanya kelalaian dalam memenuhi syarat-syarat yang diwajibkan oleh peraturan perundang-undangan yang mengancam kelalaian itu dengan batalnya putusan yang bersangkutan atau pengadilan tidak berwenang atau melampaui batas kewenangannya sebagaimana yang dimaksud dalam Pasal 30 Undang-Undang Nomor 14 tahun 1985 yang telah diubah dengan Undang-Undang Nomor 5 Tahun 2004 dan perubahan kedua dengan Undang-Undang Nomor 3 Tahun 2009;

2. Terlepas dari pertimbangan tersebut di atas menurut pendapat Mahkamah Agung amar putusan Pengadilan Tinggi Agama Semarang yang menguatkan putusan pengadilan agama Pati harus diperbaiki;

3. Permohonan kasasi yang diajukan Winarti binti Rasdi tersebut harus ditolak dengan perbaikan Amar putusan pengadilan Tinggi Agama Semarang Nomor 35/Pdt/G/2010/PTA.Smg Semarang tanggal 6 April $2010 \mathrm{M}$ yang menguatkan putusan pengadilan agama Pati nomor 1152/Pdt.G/2008/PA.Pt pada tanggal 9 November 2009 ;

4. Karena permohonan kasasi dari pemohon kasasi ditolak maka pemohon kasasi dihukum untuk membayar biaya perkara dalam tingkat kasasi;

5. Memperhatikan pasal-pasal dari Undang-Undang Nomor 48 Tahun 2009, Undang-Undang Nomor 14 Tahun 1985 sebagaimana yang telah diubah dengan UU Nomor 5 tahun 2004 dan perubahan kedua dengan Undang-Undang Nomor 3 tahun 2009, Undang-Undang Nomor 7 Tahun 1989 sebagaimana yang telah diubah dengan Undang-Undang Nomor 3 Tahun 2006 dan perubahan kedua dengan 
Undang-Undang Nomor 50 Tahun 2009 serta peraturan perundangundangan lain yang bersangkutan.

\section{Putusan Mahkamah Agung Nomor 420K/AG/2010 tentang Pembagian Waris Anak Angkat}

Kewenangan untuk menyelesaikan sengketa dibidang hukum keluarga(family law), dalam hal ini perkawinan dan waris masih menjadi kewenangan Pengadilan Agama. Adapun hukum materil yang dipakai oleh PengadilanAgama khusus tentang sengketa perkawinan didasarkan pada ketentuan yangada dalam Undang-Undang Nomor 1 Tahun 1974 tentang Perkawinan dan Intruksi Presiden Nomor 1 Tahun 1991 tentang Kompilasi Hukum Islam (KHI).

Mengenai Kompilasi Hukum Islam yang berupa Intruksi Presiden secara yuridis kekuatan berlakunya lemah, akan tetapi padapraktiknya ia dipakai sebagai pedoman oleh Pengadilan Agama dalam menerima, memeriksa, dan memutus sengketa antara umat Islam di bidang Perkawinan (buku 1), kewarisan (buku 2), dan wakaf (buku3). Masyarakat pencari keadilan pun tidak begitu mempermasalahkan. Dengan demikian dasar berlakunya dari Kompilasi Hukum Islam lebih didasarkan pada kondisi bahwa KHI (fiqih Indonesia) merupakan hukum yang hidup (living law), yaitu sebuah hukum yang dipatuhi oleh masyarakat karena memang sesuai dengan kondisi masyarakat dan kesadaran hukum masyarakat.

Kewenangan Pengadilan Agama untuk memeriksa, memutus dan menyelesaikan perkara di bidang hukum waris meliputi:

1) Penentuan siapa yang menjadi ahli waris;

2) Penentuan mengenai harta peninggalan;

3) Penentuan mengenai bagian masing-masing ahli waris;

4) Pelaksanaan pembagian harta peninggalan;

5) Penetapan pengadilan atas permohonan seseorang tentang penentuan siapa yang menjadi ahli waris dan penentuan bagian masing-masing ahli waris.

Dalam memperbaiki amar putusan Pengadilan Tinggi Agama Semarang Nomor 35/Pdt/G/2010/PTA.Smg Semarang tanggal 6 April 2010 yang menguatkan Putusan Pengadilan Agama Pati Nomor 1152/Pdt.G/2008/PA.Pt pada tanggal 9 November 2009 sehingga Amar yang menghasilkan putusan bahwa permohonan banding dari pembanding diterima dan amar Putusan Pengadilan Agama Pati sehingga amar diperbaiki.

Putusan Mahkamah Agung Nomor 420K/AG/2010 menyebutkan bahwa Pembanding mendapat hukuman untuk membayar biaya perkara dalam tingkat kasasi sebesar Rp 150.000,- (seratus lima puluh ribu rupiah) dan menghukum Pemohon Kasasi/Tergugat untuk 
membayar biaya perkara dalam tingkat kasasi sebesar Rp500.000,- (lima ratus ribu rupiah). Demikian isi dari Putusan MA Nomor 420K/AG/2010 yang dikeluarkan pada hari Selasa tanggal 31 Agustus 2010.

Hasil dari Putusan Mahkamah Agung Nomor 420K/AG/2010 telah menjawab berbagai permasalahan yang di masalahkan dalam perkara sengketa waris dalam kasus ini, bahwa dalam Putusan Mahkamah Agung Nomor 420K/AG/2010 juga telah membagi bagianbagian ahli waris terhadap sengketa waris yang diperebutkan. Adapun bagian masing-masing ahli waris manurut Putusan Mahkamah Agung Nomor 420K/AG/2010. Dari pembagian harta waris bagi masingmasing ahli waris yang telah diputuskan Mahkamah Agung Nomor 420K/AG/2010 menegaskan bahwa perkara sengketa waris yang diperebutkan telah usai dan dapat dibagi rata kepada para ahli waris yang sah sesuai dengan hasil perhitungan dari Putusan Mahkamah Agung Nomor 420K/AG/2010 yang didasari oleh Kompilasi Hukum Islam.

\section{SIMPULAN}

Hasil penelitian menunjukkan bahwa pertama, Keputusan Pengadilan Agama Pati Nomor 1152/Pdt.G/2008/PA.Pt tentang Pembagian Waris Anak Angkat adalah mengabulkan sebagian gugatan para penggugat, menetapkan ahli waris yang sah dan menetapkan besaran bagian masing-masing ahli waris terhadap harta waris, menghukum Tergugat untuk membayar uang paksa (dwangsom) atas keterlambatan pelaksanaan penyerahan harta warisan almarhum, serta menghukum Tergugat untuk membayar seluruh biaya perkara. Kedua, Keputusun Pengadilan Tinggi Agama Semarang Nomor 35/Pdt.G/2010/PTA.Smg tentang Pembagian Waris Anak Angkatmemutuskan untuk menguatkan Putusan Pengadilan Agama Pati Nomor 1152/Pdt.G/2008/PA.Pt. Hal ini sudah tepat dan benar menurut hukum.

Ketiga, Pertimbangan Mahkamah Agung dalam putusan Nomor 420K/AG/2010 tentang Pembagian Waris Anak Angkat sudah benar karena judex facti tidak salah dalam menerapkan hukum. Menurut pendapat Mahkamah Agung amar putusan Pengadilan Tinggi Agama Semarang yang menguatkan putusan Pengadilan Agama Pati harus diperbaiki dengan pertimbangan objek sengketa yang berupa harta bersama maka harta bersama harus dibagi terlebih dahulu antara almarhum dan ahli waris. 


\section{DAFTAR PUSTAKA}

Amanat, Anisistus, Membagi Warisan Berdasarkan Pasal-Pasal Hukum Perdata, Jakarta: Raja Grafindo Persada, 2000.

Amiruddin dan Asikin, Zainal, Pengantar Metode Penelitian Hukum, Jakarta: Raja Grafindo Persada, Jakarta, 2012.

A. Pitlo, Hukum Waris Menurut Kitab Undang-Undang Hukum Perdata, Jakarta: Intermasa, 1979.

Arikunto, Suharsimi, Prosedur Penelitian Suatu Pendekatan Praktek, Yogyakarta: Rineka Cipta, 1996.

Ash-Shidieqy, Hasbi, Fiqhul Mawaris, Hukum-Hukum Waris Islam, cet. I, Jakarta: Bulan Bintang, 1973.

As-Sabuny, M. Ali, alih bahasa A.M. Basmalah, Pembagian Waris Menurut Islam, Jakarta: Gema Insani Press, 1996.

Chainur Arrasyid, Dasar-Dasar Ilmu Hukum, Jakarta, Sinar Grafika, 2001.

Daradjat, Zakiah dkk, Ilmu Figh cetakan II, Yogyakarta: PT. Dana Bhakti Wakaf, 1995.

Dimyati Khudzaifah dan Wardiono Kelik, Metode Penelitian Hukum, Surakarta: Fakultas Hukum UMS, 2004.

Hadikusuma, Hilman, Hukum Waris Adat, cet. VI, Fajar Agung, Jakarta, 1987.

Hasbi Ash-Shiddieqy, Fiqh Mawaris, Semarang: Pustaka Rizki Putra, 2001.

Hilman Hadikusuma, Hukum Waris Indonesia, Bandung: Citra Aditya Bakti, 2010.

H.M.Hasballah Thaib, Tajdid, Reaktualisasi dan Elastisitas Hukum Islam, Tesis, Konsentrasi Hukum Islam Program Pascasarjana Universitas Sumatera Utara, Medan, 2002.

Husein Hamid Hassan, Nazhariyah Al-Mashlahah Fi Al-Fiqh Al-Islami, (Kairo: Al-Mutanabbi, 1981), hal. 4, dalam Jamaluddin, Analisis Hukum Perkawinan Terhadap Perceraian Dalam Masyarakat Kota Lhokseumawe Dan Kabupaten Aceh Utara, Disertasi, PPs-USU, Medan 2008.

Soraya Siregar, Akibat Hukum Pengangkatan Anak Terhadap Harta Warisan Orang Tua Angkatnya Pada Etnis Tionghoa, Jurnal Hukum ISSN 2089-1407, 2017. 